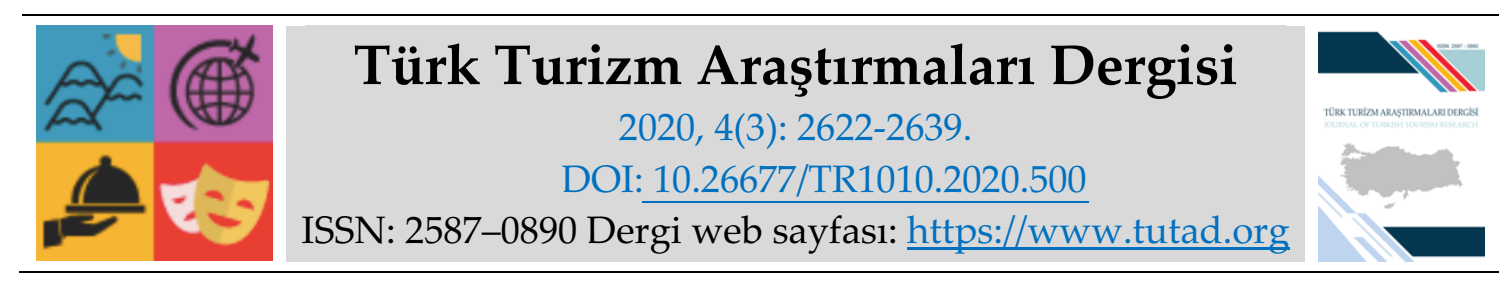

ARASTIRMA MAKALESI

\title{
Rekreasyonel Talepler ve Sosyo-Demografik Özellikler Arasındaki İlişkiler: Bilecik Şehri Örneği
}

Dr. Öğr. Üyesi Ayşe OKUYUCU, Bilecik Şeyh Edebali Üniversitesi, Fen-Edebiyat Fakültesi, Bilecik, e-posta: ayse.okuyucu07@gmail.com

ORCID: https://orcid.org/0000-0002-4415-6520

Öz

Rekreasyonel faaliyetler boş zaman endüstrisinin parçasıdır. Günümüzde özellikle kentlerde rekreasyonel faaliyetlere olan talep giderek artmaktadır. Bu nedenle kentlerde ve kentlerin yakın çevrelerinde rekreasyonel alanların oluşturulmasına verilen önem de artmaktadır. Rekreasyon katılımcılarının sosyo-demografik durumu ile talep arasındaki ilişkiler, yapılacak yatırımların belirlenmesinde önemli olabilmektedir. Bu nedenle bu çalışmada yerel halkın rekreasyonel taleplerinin belirlenmesi ve sosyo-demografik özellikleri arasındaki farkların açılanması amaçlanmıştır. Araştırma evreni Bilecik şehrinde yaşayan yerel halktır. Çalışmada nicel araştırma yöntemleri kullanılmıştır. Birincil verilerin toplanmasında anket tekniği uygulanmıştır. Veriler kolayda örnekleme yöntemi ile ve yüz yüze yapılan görüşmelerle toplanmıştır. Çalışmada, faktör analizi, t-testi ve ANOVA testi uygulanmıştır. Faktör analizi sonuçlarına göre yerel halkın; açı hava, kentsel, sportif ve kapalı alan rekreasyonel talepleri bulunmaktadır. ANOVA ve $t$ testi sonuçlarına göre; gelir düzeyi, eğitim düzeyi ve meslek grupları, cinsiyet ve medeni durum değişkenleri ile rekreasyonel talep faktörleri arasında anlamı farklılıklar bulunmuştur.

Anahtar Kelimeler: Turizm Coğrafyası, Rekreasyon, Talep, Kentsel Rekreasyon, Bilecik Şehri.

Makale Gönderme Tarihi: 24.04.2020

Makale Kabul Tarihi: 06.07.2020

\section{Önerilen Atıf:}

Okuyucu, A. (2020). Rekreasyonel Talepler ve Sosyo-Demografik Özellikler Arasındaki İlişkiler: Bilecik Şehri Örneği, Türk Turizm Araştırmaları Dergisi, 4(3): 2622-2639.

(C) 2020 Türk Turizm Araştırmaları Dergisi. 


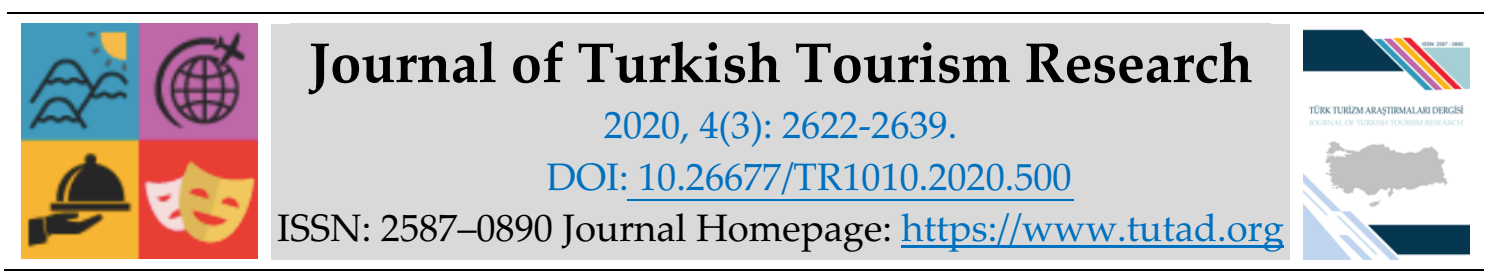

\title{
$\underline{\text { RESEARCH PAPER }}$
}

\section{Relationships Between Recreational Demands and Socio-Demographic Characteristics: The Case of Bilecik City}

Assistant Prof. Dr. Ayşe OKUYUCU, Bilecik Şeyh Edebali University, Faculty of Arts and Sciences, Bilecik, e-mail: ayse.okuyucu07@gmail.com ORCID: https://orcid.org/0000-0002-4415-6520

\begin{abstract}
Recreational activities are part of the leisure industry. Today, the demand for recreational activities are growing, especially in cities. For this reason, put emphasis on the creation of recreational areas at cities and the surrounding areas of the cities is increasing. The relationship between recreation participants' socio-demographic status and demand can be important at determining the investments will be made. Therefore, in this study, it is aimed to determine the recreational demands of the local people and to explain the differences between their socio-demographic characteristics. The research population is the local people living at the Bilecik city. Quantitative research methods have been used in the research. Questionnaire technique has been applied to collect primary data. The data has been collected by easy sampling method and face to face interviews. In the study, factor analysis, t-test and ANOVA test has been used. According to the results of the factor analysis the local people have outdoor, urban, sportive and indoor recreational demands. According to ANOVA and $t$ test results; significant differences have been found between income level, education level and occupational groups, gender and marital status variables and recreational demand factors.
\end{abstract}

Keywords: Tourism Geography, Recreation, Demand, Urban Recreation, Bilecik City.

Received: 24.04 .2020

Accepted: 06.07.2020

\section{Suggested Citation:}

Okuyucu, A. (2020). Relationships Between Recreational Demands and Socio-Demographic Characteristics: The Case of Bilecik City, Journal of Turkish Tourism Research, 4(3): 2622-2639.

(C) 2020 Türk Turizm Araştırmaları Dergisi. 


\section{GİRIŞ}

Günümüzde dünya nüfusunun yarısı kentsel alanlarda yaşamaktadır. Çoğu kent sakini için yakın mesafede iyi nitelikli rekreasyonel alanların olması çok önemlidir. Şehir yaşamı ve çalışma hayatı insanların günlük stresini arttırmaktadır. Gerçekleştirilen rekreasyonel etkinlikler insanların günlük iş yüklerinden ve sıkıntılarından uzaklaşmasını sağlamaktadır. Rekreasyonel aktiviteler kısa zamanlı (<1 gün) ve eve yakın $(<8 \mathrm{~km})$ alanlarda gerçekleştirilen aktivitelerdir (Morelle vd., 2018: 286). Rekreasyonel faaliyetler iş sonrası ya da hafta sonları gibi boş zamanlarında şehirlerin içinde açık ve kapalı mekânlarda ya da şehirlerin etrafında doğal çevrelerde gerçekleştirilebilmektedir.

Bireyler hem iç hem de diş mekânlarda, pasif veya aktif olarak kentsel veya kırsal alanlarda; uzaklaşmak, rahatlamak, sağlıklı olmak, birlikte olmak, heyecan yaşamak ve boş zamanlarında farklı deneyimler kazanmak gibi nedenlerle rekreasyonel etkinliklere katılmaktadırlar. Bu özellik rekreasyonun kesin bir tanımının yapılmasını güçleştirmektedir (Altintig ve Bagir, 2014: 89). Rekreasyon kelimesi, Latince 're-tekrar' ve 'creare-yaratma' sözcüklerinin birleşmesinden meydana gelmiştir ve yenilenme, bir şeyin yeniden yaratılması ya da kazanılması anlamına gelmektedir (Akten 2003'ten aktaran Kaya, 2007: 8). Dilimize Fransizca recreation kelimesinden yerleşen rekreasyon; kelime anlamı olarak; insanların boş zamanlarında, eğlence ve spor amacı ile gönüllü olarak katıldıkları etkinlikler ve ayrıca bir bölgeyi insanların eğlenme, dinlenme amaciyla kullanabilecekleri bir duruma getirme anlamlarına gelmektedir (TDK, 2020). Rekreasyon; insanların "varoluş (uyuma-yeme- içme vb.) ve geçim (çalışma, işe gidiş geliş, çocuklar için okul, kadınlar için ev işleri vb.) için gerekli olanın dışındaki tüm zamanlar" olarak tanımlanan boş zamanlarda yaptıkları faaliyetleri ifade eden bir kavramdır (Özgüç, 2003: 3). Rekreasyonel faaliyetler; insanların işten ve diğer sorumluluklarından arta kalan zamanlarında, onların eğlenme ve dinlenmelerini sağlayarak, onları tazeleyen bir faaliyettir. İnsanların rekreasyon ve turizm faaliyetlerinde neden yer aldığını anlamak, sosyal bilimciler için giderek daha önemli ve karmaşık bir araştırma alanı haline gelmektedir. Rekreasyon bir boş zaman etkinliği olduğu için bu faaliyetlere katılımda gönüllülük esastır. Diğer bir ifade ile rekreasyon ve turizmle ilgili insan aktivitelerinde birey ve grupların gönüllülük ya da böyle aktivitelere katılma arzusu olmalıdır. Ancak rekreasyon literatüründe talep teriminin kullanımında ve sınıflandırılmasında bu karmaşıklıktan dolayı genel bir eksiklik vardır (Hall ve Page, 2006: 31).

Rekreasyonal etkinlikler sürdürüldükleri mekânın iç ya da dış mekân olma durumuna göre kapalı alan ve açık alan rekreasyonu olarak ikiye ayrılmaktadır. Rekreasyon alanının konumuna göre ise kentsel ve kırsal rekreasyon olarak sinıflandırılmaktadır. Dünya çapında kentlerin nüfusunun giderek artması, kentleri rekreasyonel aktiviteler bakımından önemli hale getirmektedir. Şehirsel rekreasyonel etkinlikler, şehir içinde açık ve kapalı mekanlarda ve genellikle 1-1.5 saatlik ulaşım mesafesinde gerçekleştirilmektedir. Parklar, kent ormanları, spor tesisleri, gece kulüpleri, kafe vb. gibi çeşitli eğlence yerleri, sinema salonları, hayvanat bahçeleri, akvaryumlar vb. alanlar şehirlerdeki başlıca rekreasyonel alanlar olarak belirtilebilir (Akova, 2013: 16). Kırsal alanlar ise şehirden çıkmış rekreasyonel aktiviteler için geniş arazi ve doğal kaynak sağlamaktadır. Genellikle 400 hektardan fazla orman, göl, gölet vb. gibi su kenarları başlıca kırsal rekreasyonel mekanlar olarak belirtilebilir (Akova, 2013: 16). Rekreasyonel aktiviteler etkinliklere katılma şekline göre; aktif ve pasif rekreasyon olarak sınıflandırılmaktadır. Çeşitli takım sporları, yüzme, bisiklet binme gibi bedensel uğraş gerektiren faaliyetler aktif rekreasyon tipidir Buna karşıllk yürüme, oturma, piknik yapma gibi faaliyetler pasif rekreasyondur (Kaya, 2007: 15-17). Rekreasyonel aktiviteler zamansal açıdan ise günlük ve tatil rekreasyonu olarak sinıflandırılmaktadır. Günlük rekreasyon bireylerin kısa mesafede ve gün içinde gerçekleştirdikleri etkinliklerdir. Tatil rekreasyonu ise; hafta sonu, bayram ve yıllık tatiller gibi boş zamanlarda gerçekleştirilen aktiviteleri içermektedir (Argan, 2013: 12-17'den aktaran Kurar 
ve Baltacı, 2014: 44). Rekreasyonel faaliyetler insanların katılma amaçları göz önüne alınarak da çeşitli şekillerde sınıflandırılmaktadır. Bunlar arasında; dinlenme, kültürel, toplumsal, sportif, turizm ve sanatsal amaçlı rekreasyon türleri yer almaktadır (Kaya, 2007: 15-17).

\section{Rekreasyonel Talep}

Modern/sanayi toplumlarının gelişmesiyle püritan çalışma etiği yükselmiştir. Ancak günümüzde sanayi sonrası (post-modern) dönüşüm sürecinde püritan değerler işlevini kaybetmeye başlamıştır. Buna karşılık "yaşamın keyfini çıkar" diyen hedonist/hazcı özelliklere sahip yeni bir etik ortaya çıkmaktadır (Kılbaş Köktaş, 2004: 4). Bununla birlikte rekreasyon faaliyetlerinin; fiziki sağlık gelişimini ve ruh sağlı̆̆ arttırması, sosyalleşme, beceri ve yeteneklerin gelişmesi, yaratıcılık, iş veriminin artması vb. gibi kişisel faydaları ve bunun yanı sıra toplumsal bütünleşmeyi sağlaması, dayanışma ve demokratik toplumların yaratılmasına katkı sağlaması gibi toplumsal faydalarının bilincine varılması rekreasyona duyulan talebi giderek arttırmaktadır (Karaküçük, 2008: 94-101). Rekreasyonel etkinliklere ve alanlara duyulan talebin artması ile kamusal alanda ve özel sektördeki rekreasyonel uygulamalar giderek yaygınlaşmakta, çeşitlenmekte ve karmaşık hale gelmektedir (Yersüren ve Özel, 2020: 1042). Bu nedenle rekreasyonel aktivitelere katılma arzusu ile bunlara katılma fırsatları arasındaki karmaşık etkileşimi belirlemek mekânsal planlama bakımından önem taşımaktadır. Rekreasyonel faaliyetlerin planlanabilmesi için öncelikle talep etme motivasyon faktörleri ile de ilişkilerin anlaşılması gerekmektedir. Örneğin insanların boş zamanlarını ve rekreasyon aktivitelerini gerçekleştirmesinin nedeninin bir kısmını; doğanın tadını çıkarmak, rutin ve sorumluluklardan kaçmak, onaylanma ve statü, sosyal güç, fiziksel egzersiz, yaratıcılık, rahatlama, kendini gerçekleştirme, sosyal bağlantı vb. gibi motivasyon kaynakları ile ilgilidir (Tablo 1) (Hall ve Page, 2006: 33).

Motivasyon konusu gibi turizm ve rekreasyonda talepler konusu da geniş bir konudur. Turizm ve rekreasyonda talep, "yeterli satın alma gücüne ve boş zamana sahip olup belirli bir zaman diliminde, belirli bir hedef doğrultusunda turistik mal ve hizmetlerden faydalanan ya da yararlanmak isteyen kişi ya da kişiler topluluğu" olarak tanımlanmaktadır (Kozak ve Akoğlan Kozak, 2012: 75). Diğer bir tanımda ise rekreasyon talebi; önceden belirlenmiş bir zamanda ve yerde, belirli bir rekreasyon fırsatına katılması öngörülen tahmini insan sayısı olarak tanımlanmaktadır. Rekreasyon alanlarına olan talebi tahmin etmenin geleneksel yöntemleri, bireylerin tercihleri hakkında çıkarımlar yapmaktır (Lee ve Schuett, 2014: 213).

Turizm talebi ve rekreasyonel talep, insanların sadece nasıl ve niçin seyahat etmeye karar verdikleri ile ilgili değildir, aynı zamanda onların turist olarak da nasıl davrandıkları, niçin belirli tipteki turizm ve rekreasyon faaliyetlerini seçtikleri vb. ile ilgilidir (Sharpley, 2006: 25). Buna göre talep motivasyonun çıktısı yani sonuç halidir. Turizm ve rekreasyon talebini; gelir düzeyi, turizm eğilimi, boş zaman ve altyapı olanakları gibi faktörler etkilemektedir (Usta, 2014: 100). Rekreasyonel talebin yapısının ve rekreasyonel ürünleri talep edenlerin anlaşılması, turizm ve rekreasyonel faaliyetlerin planlanması ve geliştirilmesinde etkili olabilmektedir.

Ekonomik faktörler boş zaman ve seyahat endüstrisinde talep üzerinde etkili olabilecek ilk faktörlerdendir. Çeşitli çalışmalar gelir düzeyindeki artış ve harcanabilir gelirlerdeki artışın rekreasyonel talebi de arttırdığını göstermektedir (Ryan, 2003: 27). Ayrıca mal ve hizmetlerin fiyatları, döviz kurları, seyahat maliyetleri, enflasyon ve ödeme kolaylıkları gibi çeşitli ekonomik faktörler de boş zaman ve seyahat endüstrisi taleplerinde etkili olabilmektedir (Ryan, 2003: 3839). Boş zaman ve seyahat talebi yalnızca ekonomik nedenlere bağlı değildir, aynı zamanda yaş, cinsiyet, eğitim düzeyi gibi toplumsal nedenlerle de ilgilidir (Ryan, 2003: 64). Turizm talebi ve boş zaman talepleri üzerinde yaş ve cinsiyetin farklılık gösterdiği çeşitli araştırmalarda 
kanıtlanmıştır (Talay vd., 2010; Şişman vd., 2019). Ayrıca meslek; gelir düzeyi ve eğitim ile de bağlantılı bir faktördür (Usta, 2014: 103). Bununla birlikte bekar, evli ya da çocuklu olup olmama, çocuk sayısı, aile ve akraba bağlılıkları vb. aile yapısı ile ilgili toplumsal özellikler de boş zaman endüstrisi talebinde etkili olabilmektedir (Kozak ve Akoğlan Kozak, 2012: 82). Moda, zevk ve alışkanlıklar, kişilik yapısı vb. gibi çeşitli psikolojik faktörler ve bunun yanı sıra reklam, tanıtım vb. gibi diğer faktörler de bireylerin boş zaman ve turizm hareketlerini talep etmesini etkilemektedir (Sharpley, 2006: 27; Usta, 2014: 104).

Tablo 1. Rekreasyonel Talep Yaratmada Etkili Olan Motivasyon Kaynakları

\begin{tabular}{|c|c|}
\hline Doğanın Tadını Çıkarmak Modern Yaşamdan & Onaylanma ve Statü \\
\hline Kaçmak & Başkalarına bir şeyler yapabildiğini gösterme \\
\hline $\begin{array}{l}\text { Bir süreliğine modern yaşamdan uzaklaşmak } \\
\text { Doğaya yakın olmak }\end{array}$ & $\begin{array}{l}\text { Yaptıklarından dolayı diğerleri tarafından } \\
\text { daha çok düşünülme isteği }\end{array}$ \\
\hline $\begin{array}{l}\text { Rutin ve Sorumluluklardan Kaçmak } \\
\text { Günlük rutini değiştirmek } \\
\text { Günlük yaşamın sorumluluklarından } \\
\text { uzaklaşmak }\end{array}$ & $\begin{array}{l}\text { Sosyal Güç } \\
\text { Başkaları üzerinde kontrol sahibi olmak } \\
\text { Yetkili bir konumda olmak }\end{array}$ \\
\hline $\begin{array}{l}\text { Fiziksel Egzersiz } \\
\text { Egzersiz için } \\
\text { Formda kalmak için }\end{array}$ & $\begin{array}{l}\text { Başkalarını Düşünme } \\
\text { Diğgerlerine yardım etme }\end{array}$ \\
\hline $\begin{array}{l}\text { Yaratıcllık } \\
\text { Yaratıcı olmak }\end{array}$ & $\begin{array}{l}\text { Teşvik Arayışı } \\
\text { Heyecan için } \\
\text { İlgili riskler nedeniyle }\end{array}$ \\
\hline $\begin{array}{l}\text { Rahatlama } \\
\text { Fiziksel olarak rahatlamak } \\
\text { Bir süreliğine zihni dinlendirmek }\end{array}$ & $\begin{array}{l}\text { Kendini Gerçekleştirme (Kendini Geliştirme, } \\
\text { Yeteneklerin Kullanımı) } \\
\text { Çabalarının sonuçlarını görmek } \\
\text { Çeşitli beceri ve yeteneklerin kullanımı }\end{array}$ \\
\hline $\begin{array}{l}\text { Sosyal Bağlantı } \\
\text { Arkadaşlarla bir araya gelmek } \\
\text { Diğer insanlardan uzaklaşmak }\end{array}$ & $\begin{array}{l}\text { Başarı, Zorluk, Rekabet } \\
\text { Beceri ve yetenekleri geliştirmek } \\
\text { Rekabet } \\
\text { Neler yapabileceğini öğrenme }\end{array}$ \\
\hline $\begin{array}{l}\text { Yeni İnsanlarla Tanışma } \\
\text { Yeni ve çeşitli insanlarla konuşmak } \\
\text { Yeni insanlarla arkadaşlık kurmak }\end{array}$ & $\begin{array}{l}\text { Zaman Öldürme, Can Sıkıntısından Kaçma } \\
\text { Kendini meşgul tutmak } \\
\text { Can sıkıntısından kurtulma }\end{array}$ \\
\hline $\begin{array}{l}\text { Heteroseksüel İletişim } \\
\text { Karşı cinsten insanlarla birlikte olmak } \\
\text { Karşı cinsten insanlarla tanışmak }\end{array}$ & $\begin{array}{l}\text { Entelektüel Estetizm } \\
\text { Aklını kullanmak } \\
\text { Kişisel değerlerimi düşünmek }\end{array}$ \\
\hline $\begin{array}{l}\text { Aile Bă̆lantısı } \\
\text { Bir süreliğine aileden uzak kalmak } \\
\text { Aileyi bir araya getirmek }\end{array}$ & \\
\hline
\end{tabular}

Kaynak: (Crandall 1980'den aktaran Hall ve Page, 2006: 33).

Yukarıda belirtilen özelliklere göre turizm talebi ile ilgili süreç beş evrede gerçekleşmektedir. Turizm ve rekreasyon talebinde kişisel, ekonomik, sosyo-kültürel ve diğer faktörlerin hepsi, turizm ve rekreasyon sürecinde etkili olmaktadır. Bireyler belirtilen tüm faktörlerin etkisi altında, ilk olarak seyahat ve boş zaman etkinlikleri için "gereksinim hisseder ve arzu" duyarlar. Talebin gerçekleşmesinde ikinci evre katılmak istedikleri etkinlikler ve seyahatler için "bilgi toplama ve değerlendirme" evresidir. Üçüncü evre "seyahat kararı/satın alma"dır. Turizm ve rekreasyon 
talebinin dördüncü evresinde "seyahat hazırlığı/deneyimi" yer almaktadır. Talebin son evresini ise "seyahat/etkinliklerinin memnuniyeti ve değerlendirmesi" oluşturmaktadır (Sharpley, 2006: 27).

Sosyo-ekonomik yapının rekreasyonel talepler üzerindeki etkisi çeşitli çalışmalarda ele alınmıştır. Örneğin çeşitli çalışmalarda rekreasyonel çekicilikler, kullanım sıklı̆̆ı ve zamanı, deneyimler vb. kullanılarak rekreasyonel taleplerin modellenmesine ilişkin çalışmalar yapılmıştır (Buason vd., 2020). Farklı kategorilerdeki ziyaretçilerin rekreasyonel talepleri üzerinde durulmuştur (Dall'Aste Brandolini, 2009). Açık hava rekreasyonundaki artış iklim, sezonsallık gibi doğal faktörlerin rekreasyonel taleplere etkisine ilişkin çalışmaları arttırmıştır (Chan ve Wichman, 2018, Willibald vd., 2019). Türkiye'de de rekreasyonel talep ve olanaklar ile ilgili çeşitli çalışmaların son yıllarda arttığ görülmektedir (Talay vd., 2010; Altınay, 2016; Eminağaoğlu vd., 2016; Okuyucu, 2018; Şişman vd., 2019). Boş zaman ve artan refah, tüketim alışkanlıklarında yaşanan değişimler, şehirleşme ve şehirli nüfusun dünya genelinde artışı rekreasyona olan talebi şehirlerde ve kırsal alanlarda giderek arttırmaktadır (Komossaa vd., 2019: 246). Talep artışı olumlu ve olumsuz etkilere neden olabilmektedir. İnsanların ne çeşit boş zaman aktivitelerine ilgili oldukları, ne kadar zaman harcadıkları, kadın ve erkek, yaşlı ve genç vb. gibi diğer gruplar arasında nasıl bir farklılık olduğunun anlaşılması, diğer bir ifade ile talebin anlaşılması turizm ve boş zaman pazarlamacıları için faydalı olacaktır. Bu bilgiler daha iyi bir turist piyasası bölümü oluşturmada ve çeşitli stratejiler geliştirmede avantaj sağlamaktadır. Bununla birlikte rekreasyonel yatırımlar kamusal kaynak harcaması ve ticari potansiyele sahip olduklarından rekreayonel talebin planlanması, hedeflerin belirlenmesi rekreasyon yönetiminde önemlidir. Ayrıca hizmetlerinin planlanması ve yönetilmesinde tüketicilerin eğilim ve taleplerinin bilinmesi esastır (Sievänen vd., 2007: 225).

Bilecik'te 1990 yılından bu yana sanayi kollarının gelişmesi, şehirdeki askeri ve idari fonksiyonların artması, 2007 yılında Bilecik Şeyh Edebali Üniversitesi'nin kurulması vb. faktörlerin etkisi ile şehirde nüfus artmıştır ve buna paralel olarak şehirden rekreasyonel talepler de artmıştır. Bilecik'te rekreasyonel alan ve etkinlikler talebi karşılamada yeterli değildir (Okuyucu, 2018: 4404). Bu nedenle Bilecik'te şehir sakinlerinin rekreasyonel talebinin belirlenmesi, şehirdeki ihtiyacın karşılanması için yapılacak planlamaları yönlendirmesi açısından önemlidir. Yukarıda belirtilen hususlardan yola çıkılarak bu çalışmada, Bilecik şehrinde yaşayan yerel halkın rekreasyonel taleplerinin belirlenmesi ve bu taleplerin hangi rekreasyon kategorisinde yoğunlaştı̆̆ının ortaya çıkarılması amaçlanmıştır. Çalışmada diğer amaç; yerel halkın rekreasyonel taleplerinin, sosyo-demografik özellikler ile aralarındaki farklılıkların belirlenmesidir.

\section{YÖNTEM}

Çalışmada, nicel araştırma yöntem ve teknikleri kullanılmıştır. Bilecik'te yaşayan yerel halkının rekreasyonel taleplerini belirlemede, alan araştırması ve anket tekniği kullanılmıştır. Çalışmada kullanılan ölçeklerin hazırlanmasında literatür taraması yapılmış, daha önce kullanılmış geçerliliği ve güvenirliği sınanmış ölçeklerden çalışmaya uygun olan ölçekler belirlenmiştir. Çalışmadaki değişkenlerin ölçümünde Sertkaya (2001), Sağlık ve Kelkit (2014), Karaşah (2017)'nin çalışmalarında kullandıkları ölçeklerden yararlanılmıştır. Anketin ilk bölümünde genel hane halkı bilgilerine ve halkın rekreasyonel davranışlarını belirlemeye yönelik kapalı uçlu sorular yer almaktadır, anketin ikinci bölümünde ise yerel halkın rekreasyonel talep ve beklentilerini belirlemeye yönelik sorular yöneltilmiştir. İkinci bölüm 5'li Likert tipi ölçek (rekreasyonel eğilim ve talep algısı için: 1, kesinlikle katılmıyorum ile 5, kesinlikle katılıyorum) ile değerlendirilmiştir. Ölçek güvenirliliği Cronbach Alpha güvenirlik katsayısı ile 
değerlendirilmiş ve elde edilen değerin $(\alpha=0,809)$ kabul edilebilir seviyenin üzerinde olduğu görülmüştür (Gürbüz ve Şahin, 2015: 317).

Çalışmanın evrenini Bilecik şehrinde yaşayan yerel halk oluşturmaktadır. Bilecik şehrinin toplam nüfusu 2017 yılında 65.578 kişidir (TÜIK, 2018). Anketler, 2017 yılı Mart-Nisan ayları arasında Bilecik şehrinde yüz yüze görüşme tekniği ile uygulanmıştır. Çalışmaya katılmayı kabul eden katılımcılardan, kolayda örnekleme yöntemiyle veriler toplanmıştır. Toplanan ve araştırmaya uygun veri sayısı 300'dür. Hata payı, eksik kodlama gibi nedenlerle 24 anket çıkarılmış ve toplamda 276 anket değerlendirmeye alınmıştır. Evren büyüklüğü 50.000 ila 100.000 ve örnekleme hatasının $\pm 0,05$ olması durumunda, 245 örneklem evreni temsil etmede yeterlidir (Yazıcıoğlu ve Erdoğan, 2004: 50). Bu durumda değerlendirmeye alınan 276 anket evreni temsil etmede yeterlidir.

Anketlerden elde edilen veriler, IBM SPSS Statistics 21.0 paket programı ile analiz edilmiştir. Yerel halkın sosyo-demografik özelliklerinin belirlenmesinde frekans ve oranlar kullanılmıştır. Yerel halkın; rekreasyonel talepleri konusundaki algıları, ifadelere verdikleri 1-5 puan aralığındaki yanıtların ortalamalarına göre hesaplanmıştır. Rekreasyonel talepler ölçeğinin yapı geçerliliği keşfedici faktör analizi (KFA) ile gerçekleştirilmiştir. Yerel halkın demografik özellikleri ile KFA sonucu belirlenen faktörlere atfedilen ortalama önem puanları arasında anlamlı farklar olup olmadığını belirmek amacı ile t-testi ve ANOVA testi kullanılmıştır. Parametrik testler olan t-testi ve ANOVA testlerinin kullanılmasında verilerin aralıklı olması ve normal dağılım göstermesi etkili olmuştur. Verilerin çarpıklık katsayısı $(-, 418)^{\prime}$ dir. Çarpıklık değerinin -1 ve +1 sinırları içinde kalması puanların normal dağılımdan önemli bir sapma göstermediğini ortaya koymaktadır (Büyüköztürk, 2015: 40). Verilerin sahip oldukları bu özelliklerinden dolayı parametrik testler uygulanmıştır. ANOVA testi sonucunda anlamlı farklılık belirlenen gruplarda, farklılığın hangi grup ya da gruplar arasında olduğunu tespit etmek için ise Tukey testi kullanılmıştır (Gürbüz ve Şahin, 2015: 233).

\section{BULGULAR}

\section{Katılımcıların Sosyo-Demografik Profili}

Rekreasyonel talep ve özelliklerin belirlenmesinde kullanıcılarının sosyo-demografik özelliklerinin belirlenmesi, rekreasyonel planlamanın ilk basamağını oluşturmaktadır (Talay vd., 2010: 148). Ankete katılan yanitlayıcıların \%53.3'ü erkeklerden, \%46.7'si kadınlardan oluşmaktadır. Katılımcıların \%51.8'i evlilerden oluşmaktadır. Katılımcılar çoğunlukla 18-30 (\%54.7) ve 31-50 (\%37.7) yaş aralığındadır. Aylık gelir ise çoğunlukla ise 1000-2000 TL (\%37.7) ve 2001-4000 TL (\%37.3) aralığında yer almaktadır. Eğitim düzeyinde ise lisans (\%50.4) ve lise (\% 27.2) mezunları en büyük paya sahiptir. Katılımcıların \%25.7'si kamuda çalışmaktadır, \%25.7'si öğrencidir ve \% 22.1'i özel sektörde çalışmaktadır (Tablo 2). 
Tablo 2. Katılımcıların Sosyo-Demografik Profili

\begin{tabular}{|c|c|c|}
\hline Değişkenler & $\mathrm{N}$ & $(\%)$ \\
\hline \multicolumn{3}{|l|}{ Cinsiyet } \\
\hline Erkek & 147 & 53.3 \\
\hline Kadın & 129 & 46.7 \\
\hline \multicolumn{3}{|l|}{ Medeni durum } \\
\hline Bekâr & 133 & 48.2 \\
\hline Evli & 143 & 51.8 \\
\hline \multicolumn{3}{|l|}{ Yaș } \\
\hline $18-30$ & 151 & 54.7 \\
\hline $31-50$ & 104 & 37.7 \\
\hline$\geq 51$ & 21 & 7.6 \\
\hline \multicolumn{3}{|l|}{ Aylık gelir (TL) } \\
\hline $1000-2000$ & 104 & 37.7 \\
\hline $2001-4000$ & 103 & 37.3 \\
\hline $4001-8000$ & 56 & 20.3 \\
\hline$\geq 8001$ & 13 & 4.7 \\
\hline \multicolumn{3}{|l|}{ Eğitim } \\
\hline İlkokul (< 8 yıl) & 29 & 10.5 \\
\hline İlköğretim ( $\geq 8$ yıl) & 19 & 6.9 \\
\hline Lise & 75 & 27.2 \\
\hline Lisans & 139 & 50.4 \\
\hline Lisans üstü & 14 & 5.1 \\
\hline \multicolumn{3}{|l|}{ Meslek } \\
\hline İşveren/kendi hesabına çalışan & 11 & 4.0 \\
\hline Kamuda çalışan & 71 & 25.7 \\
\hline Özel sektörde ücretli çalışan & 61 & 22.1 \\
\hline Ev hanimi & 20 & 7.2 \\
\hline Öğrenci & 71 & 25.7 \\
\hline Emekli & 12 & 4.3 \\
\hline Diğer & 30 & 10.9 \\
\hline
\end{tabular}

\section{Faktör Analizi}

Araştırmaya katılan yerel halkın Bilecik şehrinden rekreasyonel taleplerini belirleyebilmek için ölçekte yer alan 21 önermeye faktör analizi uygulanmıştır (Tablo 3). Keiser Meyer Olkin (KMO) değeri 0.862, Barlett Küresellik testi ise anlamlı çıkmıştır ( $p<0.05)$. Elde edilen değerler verilerin faktör analizi için uygun olduğunu göstermektedir (Gürbüz ve Şahin, 2015: 311). Faktör analizinde anlaml faktörler elde etmek için temel bileşenler analizi ve varimaks rotasyonu kullanılmıştır. Özdeğer istatistiği 1 'den büyük ve faktör yükü 0.30 'un üzerinde olan veriler dikkate alınarak faktörler belirlenmiştir (Gürbüz ve Şahin, 2015: 313) (Tablo 3).

Faktör analizi sonucuna göre, veriler dört faktör altında toplanmıştır. İlk faktör "açık alan rekreasyon talepleri", ikinci faktör "kentsel rekreasyon talepleri", üçüncü faktör "sportif rekreasyon talepleri" ve son olarak dördüncü faktör "kapalı alan rekreasyon talepleri" olarak adlandırılmıştır. Tüm faktörler toplam varyansın \%51.27'sini açıklamaktadır (Tablo 3). 
Tablo 3. Katılımcıların Bilecik Şehrinden Rekreasyonel Taleplerine Yönelik Faktör Analizi Tablosu

\begin{tabular}{lcccc}
\hline Faktörler ve değişkenler & \multicolumn{3}{c}{ Faktör Yükleri } \\
& 1 & 2 & 3 & 4 \\
\hline F1. Açık alan rekreasyon talepleri & & & \\
Kent parkları, kent içi yeşil alanlar &, 804 & & \\
Kent içi piknik alanları. &, 771 & & \\
Manzara seyri, seyir tepeleri &, 759 & \\
Göl-akarsu kenarı alanlar &, 748 & \\
Tarihi-geleneksel doku içeren alanlar &, 555 & \\
Hayvanat bahçesi &, 492 & \\
\hline
\end{tabular}

F2. Kentsel rekreasyon talepleri

Tiyatro , 649

Sinema

Buz pateni pisti , 583

Kapsamlı bir çocuk oyun alanı

Bisiklet binme alanları ve olanakları

Gösteri, sergi, konser vb. kültürel aktivite alanları

Aerobik, yoga, zumba vb. aktivite olanakları

Kurslar (Resim, ahşap boyama, müzik vb.) ,401

F3. Sportif rekreasyon talepleri

Futbol, basketbol, voleybol, tenis vb. spor sahaları

Yürüyüş, koşu vb. spor alanları

Av sporları (kara ve su avcılı̆̆ı) alanları

Su sporları alanları , 510

F4. Kapalı alan rekreasyon talepleri

Alkollü mekânlar (bar-gece kulübü vb.) ,754

Restoran, cafe vb. alan ve olanakları

AVM'ler ve çarşılar 492

\begin{tabular}{lcccc}
\hline Özdeğerler & 6.327 & 1.941 & 1.345 & 1.153 \\
\hline Açıklanan Varyans (\%) & 30.13 & 9.24 & 6.41 & 5.49 \\
\hline Toplam Açıklanan Varyans (\%) & \multicolumn{5}{c}{51.27} \\
\hline
\end{tabular}

Katılımcılar, "açık alan rekreasyon talepleri" boyutunu $(\bar{X}=4.25)$, önemli olarak algılamışlardır. Diğer boyutlara atfedilen ortalama puanlar içinde ikinci sırada "kentsel rekreasyon talepleri" $(\overline{\mathrm{X}}=3.97)$, üçüncü sırada "sportif rekreasyon talepleri" $(\overline{\mathrm{X}}=3.72)$ ve dördüncü sırada "kapalı alan rekreasyon talepleri" ( $\overline{\mathrm{X}}=3.51)$ olmuştur. Açık alan rekreasyon aktivitelerine olan talep son on yıldır giderek artmaktadır. Bunda, toplum ve bireylerde sağlıklı yaşam ve iş dengesine verilen 
önemin artması, nüfus artışı, demografik değişiklikler ve artan refah vb. gibi faktörler etkili olmaktadır (Willibald vd., 2019: 2). Bilecik şehrinde kişi başına 15,1 $\mathrm{m}^{2}$ açık-yeşil alan düşmektedir. Bu değer İmar ve İskân Bakanlığı'nın önerdiği $10 \mathrm{~m}^{2}$ aktif açık-yeşil alan değerinin üzerindedir. Bilecik şehrinde parklar ve diğer açık yeşil alan türlerinin mahallelere göre dengeli bir dağılıma sahip değildir. Yalnızca iki mahallede $10 \mathrm{~m}^{2}$ standardının üzerindedir. Diğer mahallelerde kişi başına düşen açık-yeşil alan miktarının oldukça düşük düzeydedir (Menteşe, 2019: 378). Bilecik şehrinde aktif kullanılabilen yeşil alanların başında Pelitözü Gölpark, Kent Ormanı ve Uğur Mumcu Parkı gelmektedir. Dinlenme, eğlenme, spor ve oyun gibi çeşitli amaçlarla kullanılabilecek aktif yeşil alanların azlığı, eşit olmayan dağılışı, kalitesi ve erişilebilirliği yerel halkın bu yöndeki taleplerinin yüksek olmasında etkili olmuştur. Şehir merkezlerinde yer alan alışveriş merkezleri, sinema ve tiyatro binaları, eğlenme mekânları, çocuk oyun alanları, piknik alanları, yeşil alanlar vb. gibi rekreasyonel kolaylıklara olan talep giderek artmaktadır. Bunda insanların rekreasyon alanlarına uzun süreli, saatler süren yolculuklarla değil, hemen ulaşabilmek istemeleri etkili olmaktadır (Altınay, 2016: 61). Bilecik şehrinde alışveriş merkezi bulunmamaktadır, 6 Eylül Sineması dışında sinema salonu bulunmamaktadır ve tiyatro oyunları Bilecik Tiyatro günleri kapsamında düzenlenen festivalde kasım ayı boyunca sergilenmektedir. Bununla birlikte kent içerisinde öğrencilere yönelik kafeler dışında eğlence mekanlarının olmaması, yeşil alanların azlığı vb. gibi eksiklikler yerel halkın "kentsel rekreasyon" talepleri faktöründe ikinci sırada gelmesinde etkili olmuştur. Üçüncü sırada gelen "sportif rekreasyon talepleri" yine kent içerisindeki aktif olarak kullanılabilecek yeşil alanların ve açık alan spor aletlerinin azlığından ve şehirdeki spor salonlarının az olmasından kaynaklanmaktadır. Dördüncü sırada "kapalı alan rekreasyon talepleri" faktörünün ortaya çıkmasında ise Bilecik şehrindeki sinema, tiyatro, alışveriş merkezi, eğlence mekanları vb. alanlardaki eksiklikler etkili olmuştur.

Rekreasyonel talepler konusunda faktörlere ve ifadelere atfedilen önem derecelerine göre bulunan "ortalama" değerler Tablo 4'te verilmiştir. Açı alan rekreasyon talepleri faktöründe; manzara seyri, seyir tepeleri $(\bar{X}=4.42)$, kent parkları, kent içi yeşil alanlar $(\bar{X}=4.37)$, tarihigeleneksel doku içeren alanlar $(\bar{X}=4.33)$ ifadeleri en fazla önem atfedilen ifadeler olmuştur. Bununla birlikte bu faktörde yer alan pek çok ifade 4 (Katılıyorum) ile 5 (Kesinlikle katılıyorum) arasında değişen puan ortalamasına sahiptir. Kent içerisindeki yeşil alanlar ve tarihi dokuların varlığı mekân-insan ilişkisinin oluşması ve sürdürülebilirliğinde önem taşımaktadır (Kurtar ve Somuncu, 2013: 36). Nitekim günümüzde şehirlerde açık yeşil alanlar kadar kültürel miras alanları, tarihi dokular rekreasyon anlamında önem kazanmaktadır. Kentsel rekreasyon talepleri faktöründe; çeşitli kurslar $(\bar{X}=4.36)$, sinema $(\bar{X}=4.30)$, gösteri-sergi-konser vb. gibi çeşitli etkinlikler $(\bar{X}=4.24)$ ve tiyatro $(\bar{X}=4.17)$ yerel halkın en çok talep ettiği rekreasyon alanları olmuştur. Sportif rekreasyon talepleri faktöründe yürüyüş, koşu vb. spor alanları $(\bar{X}=4.14)$, futbol, basketbol, voleybol, tenis vb. spor sahaları ( $\overline{\mathrm{X}}=3.92)$ en fazla ortalamaya sahip ifadeler olmuştur. Kapalı alan rekreasyon talepleri faktöründe ise AVM'ler-çarşılar $(\bar{X}=4.37)$ ve restoran, cafe vb. alanlar $(\bar{X}=3.82)$ en fazla talep edilen rekreasyonel olanaklar olmuştur. Bilecik şehrinde rekreatif faaliyetler veya rekreasyon alanları yaratılması ile kent sakinlerine bu imkanların sunulması sürdürülebilir bir kent gelişimi önem taşımaktadır. Nitekim sürdürülebilir kentsel gelişmede doğal çevrenin korunması kadar kentin sağladığı olanakları ve kültürel çeşitliliği arttırmak gerekmektedir. Ayrıca kentte özgü geliştirilecek bir takım rekreatif faaliyet ve alanlar kentin marka olasına da önemli katkılar sağlamaktadır (Yüksel ve Yeşil, 2017: 356-357). 
Tablo 4. Rekreasyon Talebi Faktörleri ve İfadelerine Göre Elde Edilen Ortalamalar

\begin{tabular}{lcc}
\hline Faktörler ve ifadeler & Ortalama & Standart Sapma \\
\hline F1. Açık alan rekreasyon talepleri & 4,25 &, 66642 \\
Manzara seyri, seyir tepeleri & 4,42 & 0,77947 \\
Kent parkları, kent içi yeşil alanlar & 4,37 & 0,86193 \\
Tarihi-geleneksel doku içeren alanlar & 4,33 & 0,79235 \\
Kent içi piknik alanları. & 4,30 & 0,85289 \\
Göl-akarsu kenarı alanlar & 4,28 & 0,86027 \\
Hayvanat bahçesi & 3,84 & 1,25577 \\
\hline F2. Kentsel rekreasyon talepleri & 3,97 &, 81806 \\
Kurslar (Resim, ahşap boyama, müzik vb.) & 4,36 & 3,14105 \\
Sinema & 4,30 & 0,96941 \\
Gösteri, sergi, konser vb. kültürel aktivite alanları & 4,24 & 0,8867 \\
Tiyatro & 4,17 & 0,96418 \\
Kapsamlı bir çocuk oyun alanı & 4,10 & 1,1605 \\
Bisiklet binme alanları ve olanakları & 3,99 & 1,07862 \\
Buz pateni pisti & 3,34 & 1,29893 \\
Aerobik, yoga, zumba vb. aktivite olanakları & 3,29 & 1,29448 \\
\hline F3. Sportif rekreasyon talepleri & 3,72 &, 84358 \\
Yürüyüş, koşu vb. spor alanları & 4,14 & 1,02601 \\
Futbol, basketbol, voleybol, tenis vb. spor sahaları & 3,92 & 1,09777 \\
Su sporları alanları & 3,83 & 1,18833 \\
Av sporları (kara ve su avcıllı̆ı) alanları & 3.00 & 1,49423 \\
\hline F4. Kapalı alan rekreasyon talepleri & 3.51 &, 80469 \\
AVM'ler ve çarşılar & 4.37 &, 91961 \\
Restoran, cafe vb. alan ve olanakları & 3,82 & 1,23333 \\
Alkollü mekânlar (bar-gece kulübü vb.) & 2,34 & 1,55620 \\
\hline
\end{tabular}

\section{Sosyo-Demografik Değişkenlere Göre Rekreasyonel Taleplerde Farklılaşma}

Bireylerin sosyo-demografik özellikleri; aktivite, davranış, yaşam biçimi ve tercihler üzerinde etkili olmaktadır. Veri analizi sonuçlarında destekleyici bir çerçeve sağlamak için, araştırmaya katılanların sosyo-demografik karakteristikleri ile rekreasyonel taleplerinin araştırılması önemlidir. Bu nedenle bu kısımda faktör analizi sonucunda elde edilen dört faktör ile katılımcıların sosyo-demografik özellikleri arasında anlamlı farklılıklar olup olmadığ araştırılmıştır. Bu farklılıkların belirlenmesinde $\mathrm{t}$ testi ve ANOVA testi kullanılmıştır.

Tablo 5'e göre rekreasyonel talep puanları karşılaştırıldığında, faktör analizi sonucunda elde edilen açık alan rekreasyonu ve kentsel rekreasyon taleplerinde kadınların ortalamalarının erkeklere göre daha yüksek olduğu görülmektedir. Ancak sportif rekreasyon talebi ve kapalı alan rekreasyon talepleri bakımından kadınların ortalamaları erkeklerden düşüktür. Cinsiyete göre yapılan $\mathrm{t}$ testinden elde edilen sonuçlara göre "kentsel rekreasyon talepleri" faktörüne kadın katılımcllar daha fazla önem atfetmiştir ve cinsiyete göre elde edilen bu farklılık anlamdır $\left(\mathrm{t}_{(242,944)=}\right.$ 2,131; $\mathrm{p}<0.05)$. Sportif rekreasyon talepleri faktörüne erkekler $(\bar{X}=3.85)$, kadınlara göre $(\bar{X}=3.58)$ daha fazla önem atfetmişlerdir. Buna göre sportif rekreasyonel faaliyetleri talep etmede erkek ve kadın katılımcılar arasında anlamlı bir farklılık vardır $\left(t_{(273,605)=-}-2,763 ; p<0.05\right)$, (Tablo 5).

Açık hava rekreasyonu talebi faktöründe bekarların $(\bar{X}=3.29)$, ortalamaları evlilere $(\bar{X}=4.22)$, göre daha yüksektir, ancak aralarında anlamlı bir ilişki yoktur ( $p>0.05)$. Kentsel rekreasyon talepleri 
ve sportif rekreasyon talepleri faktörlerinde ise evli katılımcıların ortalamaları bekar katılımclara göre yüksektir. Ancak $\mathrm{t}$ testi sonuçlarına göre aralarındaki farklılık hiçbir faktör için anlamlı değildir ( $p>0.05$ ). Medeni durum değişkenine göre yapılan $t$ testi sonuçlarına göre kapalı alan rekreasyon talepleri faktörüne bekarlar $(\bar{X}=3.62)$, evlilere göre $(\bar{X}=3.41)$ daha fazla önem atfetmişlerdir ve aralarındaki fark anlamlıdır $\left(\mathrm{t}_{2(23,158)}=, 509 ; \mathrm{p}<0.05\right)$, (Tablo 5).

Tablo 5. Cinsiyet ve medeni durum grupları arasında faktörler açısından farklılıklar

\begin{tabular}{lcccc}
\hline Cinsiyet & $\begin{array}{c}\text { Kadın } \\
(\bar{X})\end{array}$ & Erkek $(\bar{X})$ & F değeri & p değeri \\
\hline Faktörler & & & & \\
F1. Açık alan rekreasyon talepleri & 4.29 & 4.23 & 2,809 &, 470 \\
F2. Kentsel rekreasyon talepleri & 4.09 & 3.87 &, 053 &, $034^{*}$ \\
F3. Sportif rekreasyon talepleri & 3.58 & 3.85 & 1,163 &, $0006^{*}$ \\
F4. Kapalı alan rekreasyon talepleri & 3.48 & 3.54 &, 171 &, 509 \\
\hline Medeni durum & Evli $(\bar{X})$ & Bekar $(\bar{X})$ & F değeri & p değeri \\
\hline Faktörler & & & & \\
F1. Açık alan rekreasyon talepleri & 4,22 & 4,29 &, 056 &, 341 \\
F2. Kentsel rekreasyon talepleri & 3,98 & 3,96 &, 404 &, 860 \\
F3. Sportif rekreasyon talepleri & 3,80 & 3,65 &, 899 &, 150 \\
F4. Kapalı alan rekreasyon talepleri & 3,41 & 3,62 & 1,805 &, $038^{*}$ \\
\hline
\end{tabular}

${ }^{* *} P \leq 0.01 \quad{ }^{*} P \leq 0.05$

Araştırma kapsamında yaş grupları, gelir durumu, eğitim ve meslek grupları değişkenlerinin, rekreasyonel taleplerde anlamlı farklılık gösterip göstermediğini belirlemek amacıyla ANOVA testi uygulanmıştır. Sonuçları anlamlı çıkan değişken ve faktörler arasında farkların hangi gruplar arasında olduğunu belirlemek amacıyla Tukey testi uygulanmıştır. ANOVA testi sonuçlarına göre yaş grupları ile rekreasyonel talep faktörleri arasında istatistiksel olarak anlamlı farklar bulunamamıştır. Ancak kapalı alan rekreasyon talepleri faktörü ile gelir düzeyi arasında istatiksel olarak anlamlı bir farklılık bulunmaktadır (Tablo 6). Tukey testi sonuçlarına göre gelir düzeyi 8.001 TL ve üzeri olan grup ile gelir düzeyi 1.000-2.000 TL ve 2.001-4.000 TL arasındaki gelir grupları arasında istatistiksel olarak anlamlı bir farklılıklar bulunmuştur. Kapalı alan rekreasyon talebi $8.001 \mathrm{TL}$ ve üzeri gelire sahip olanlarda $(\bar{X}=4.44)$ puan ortalama ile daha fazladır. Buna göre gelir düzeyi yükseldikçe restoran, AVM gibi kapalı alan rekreasyon talebi artmaktadır. Çalışmada ayrıca eğitim düzeyi değişkeni ile "kentsel rekreasyon talepleri" ve "kapalı alan rekreasyon talepleri" faktörleri arasında anlamlı bir farklılık bulunmuştur. Tukey testinden elde edilen sonuçlara göre lisans $(\bar{X}=4.14)$ ve lisans üstü $(\bar{X}=4.34)$ düzeyde eğitime sahip olanlar, ilkokul $(\bar{X}=4.62)$ düzeyinde eğitime sahip olanlara nazaran "kentsel rekreasyon talepleri" faktörüne daha fazla önem atfetmişlerdir. Buna göre eğitim düzeyi yüksek olan grupların, kentsel rekreasyon taleplerinin daha fazla olduğu söylenebilir. Eğitim düzeyi değişkeni ile "kapalı alan rekreasyon talepleri" faktörü arasında da anlamlı bir farklılık bulunmuş̧tur. Tukey testi sonuçlarına göre, lisans $(\bar{X}=3.62)$ ve lisans üstü $(\bar{X}=4,12)$ düzeyinde eğitime sahip olanlar, "kapalı alan rekreasyon talepleri" faktörüne ilkokul düzeyinde eğitime sahip olanlara göre $(\bar{X}=3,08)$ anlamlı bir şekilde daha fazla önem atfetmiş̧lerdir. Buna göre Bilecik şehrinde eğitim düzeyi yüksek olan grupların kapalı alanlarda gerçekleştirilen rekreasyonel alanları daha fazla talep etmektedir. Tukey testi sonuçlarına göre eğitim düzeyi lisans üstü olanlar $(\bar{X}=4,12)$ lise düzeyinde eğitime sahip olanlara göre $(\bar{X}=3.34)$ kapalı alan rekreasyon talepleri faktörüne daha fazla önem atfetmiştir ve aralarında anlamlı farklılık bulunmaktadır. 
Eğitim düzeyi, meslek ve gelir düzeyi birbiri ile doğru orantılıdır. Bir kimsenin eğitim düzeyi yükseldikçe, meslek ve gelir düzeyinin de buna bağlı olarak artması beklenmektedir (Kozak ve Akoğlan Kozak, 2012: 82). Bu nedenle bu durum meslek ve rekreasyonel talep arasındaki ilişkiye de yansımaktadır. ANOVA testi sonuçlarına göre meslek grupları değişkenleri ile "kentsel rekreasyon talepleri" faktörü arasında istatistiksel olarak anlamlı farklar bulunmuştur (Tablo 6). Kamu çalışanları $(\bar{X}=4.21)$, işveren/kendi hesabına çalışanlara $(\bar{X}=3.35)$ göre kentsel rekreasyon talepleri faktörüne anlamlı bir şekilde daha fazla önem atfetmiştir $(F(2,783)=6.269 ; p<0.05)$. Meslek grupları değişkeni "kapalı alan rekreasyon talepleri" faktörü ile istatiksel olarak anlamlı farklılıklar göstermiştir. Hangi gruplar arasında farklılık olduğunu test etmek için yapılan Tukey testi sonuçlarına göre, kapalı alan rekreasyon taleplerine, kamu çalışanları $(\bar{X}=3.75)$ ev hanımlarına göre $(\bar{X}=3.12)$ daha fazla önem atfetmiştir $(\mathrm{F}(2,970)=6.269 ; \mathrm{p}<0.05)$.

Tablo 6. Yaş, Gelir, Eğitim ve Meslek Değiş̧kenleri ile Rekreasyon Talepleri Faktörlerine Göre One-way ANOVA Sonuçları

\begin{tabular}{|c|c|c|c|c|}
\hline $\begin{array}{l}\text { Sosyo-demografik } \\
\text { değişkenler }\end{array}$ & $\begin{array}{l}\text { F1. Açık alan } \\
\text { rekreasyon talepleri }(\overline{\mathrm{X}})\end{array}$ & $\begin{array}{l}\text { F2. Kentsel } \\
\text { rekreasyon } \\
\text { talepleri }(\overline{\mathrm{X}})\end{array}$ & $\begin{array}{l}\text { F3. Sportif } \\
\text { rekreasyon } \\
\text { talepleri }(\overline{\mathrm{X}})\end{array}$ & $\begin{array}{l}\text { F4. Kapalı } \\
\text { alan } \\
\text { rekreasyon } \\
\text { talepleri }(\overline{\mathrm{X}})\end{array}$ \\
\hline \multirow{2}{*}{ Yaş } & $\mathrm{F}=1,107$ & $F=1,826$ & $\mathrm{~F}=, 865$ & $\mathrm{~F}=1,822$ \\
\hline & $\mathrm{p}=, 332$ & $\mathrm{p}=, 163$ & $\mathrm{p}=, 422$ & $\mathrm{p}=, 164$ \\
\hline $18-30$ & 4,2969 & 3,9901 & 3,7848 & 3,5872 \\
\hline $31-50$ & 4,2292 & 4,0144 & 3,6587 & 3,4487 \\
\hline$\geq 51$ & 4,0794 & 3,6488 & 3,6190 & 3,2857 \\
\hline \multirow{2}{*}{ Gelir } & $\mathrm{F}=, 445$ & $F=2,129$ & $\mathrm{~F}=, 095$ & $\mathrm{~F}=7,574$ \\
\hline & $\mathrm{p}=, 721$ & $\mathrm{p}=, 097$ & $p=, 963$ & $\mathrm{p}=, 000^{* *}$ \\
\hline $1000-2000$ & 4,1987 & 3,8413 & 3,7115 & 3,3942 \\
\hline $2001-4000$ & 4,2945 & 3,9867 & 3,7524 & 3,4498 \\
\hline $4001-8000$ & 4,2946 & 4,1272 & 3,7188 & 3,6310 \\
\hline$\geq 8001$ & 4,2179 & 4,2596 & 3,6346 & 4,44 \\
\hline \multirow{2}{*}{ Eğitim } & $\mathrm{F}=, 864$ & $F=5,274$ & $F=1,662$ & $F=6,011$ \\
\hline & $\mathrm{p}=, 486$ & $\mathrm{p}=, 000^{* *}$ & $\mathrm{p}=, 159$ & $\mathrm{p}=, 000^{* *}$ \\
\hline İlkokul (< 8 yıl) & 4,1379 & 3,62 & 3,5086 & 3,08 \\
\hline İlköğretim ( $\geq 8$ yıl) & 4,2807 & 3,98 & 4,0395 & 3,60 \\
\hline Lise & 4,1689 & 3,74 & 3,6233 & 3,34 \\
\hline Lisans & 4,3141 & 4,14 & 3,7896 & 3,62 \\
\hline Lisans üstü & 4,3333 & 4,34 & 3,6429 & 4,12 \\
\hline \multirow{2}{*}{ Meslek } & $\mathrm{F}=1,774$ & $\mathrm{~F}=2,783$ & $\mathrm{~F}=1,112$ & $\mathrm{~F}=2,970$ \\
\hline & $\mathrm{p}=, 105$ & $\mathrm{p}=, 012^{*}$ & $\mathrm{p}=, 356$ & $\mathrm{p}=, 008^{*}$ \\
\hline $\begin{array}{l}\text { İşveren/kendi } \\
\text { hesabına çalışan }\end{array}$ & 3,9697 & 3,35 & 3,5909 & 3,03 \\
\hline Kamuda çalışan & 4,2958 & 4,21 & 3,6479 & 3,75 \\
\hline $\begin{array}{l}\text { Özel sektörde } \\
\text { ücretli çalışan }\end{array}$ & 4,3443 & 3,9816 & 3,8975 & 3,58 \\
\hline Ev hanimı & 4,2417 & 3,9813 & 3,4250 & 3,12 \\
\hline Öğrenci & 4,3263 & 3,9630 & 3,7113 & 3,47 \\
\hline Emekli & 4,1667 & 3,6250 & 3,6875 & 3,28 \\
\hline Diğer & 3,9556 & 3,7833 & 3,8500 & 3,42 \\
\hline
\end{tabular}

$P \leq 0.01{ }^{*} P \leq 0.05$

\section{SONUÇ ve ÖNERILER}

Önceleri ağırlıklı olarak kırsal bir fonksiyona sahip olan Bilecik şehri, 1990'lı yıllardan sonra kalkınma öncelikli iller kapsamına alınmıştır. Bununla birlikte şehirde askeri, idari fonksiyonların artması ve üniversitenin kurulmasını takiben nüfusu zaman içinde artmıştır. 
Böylece Bilecik şehri nüfusunun fonksiyonel karakteri de zaman içinde değişmiştir (Özgür, 1994: 181-182). Bilecik şehrinde nüfusun giderek kentlileşmesi beraberinde rekreasyonel talepleri de artırmıştır. Ancak şehirdeki rekreasyonel arz, talep edilenin altındadır. Bunda çeşitli faktörler etkili olabilmektedir. Özellikle Bilecik şehrinin; Eskişehir, Bursa, Adapazarı, İzmit ve İstanbul gibi sosyal ve eğlence çekicilikleri fazla olan şehirlere yakın olması etkili olmaktadır (Okuyucu, 2018: 4403). Bu şehirlerden özellikle Eskişehir, Bursa, Adapazarı 70-90 km arasında mesafededir olduğu için günübirlik gidiş geliş zonunda yer almaktadır. Ancak çoğu kent sakini için yakın mesafede iyi nitelikli bir rekreasyonel alan olması çok taşımaktadır (Morelle vd., 2018: 286, 294). Rekreasyonel alanların yakın mesafede olması, rekreasyonel kullanımda etkili olmaktadır. Ancak rekreasyonel talepler üzerinde aydınlatma, çöp kutusu, oturma elemanları, süs havuzu, spor alanı, yürüyüss parkuru ve otopark vd. gibi donatı elemanlarının yeterli olması da önem taşımaktadır (Serbest Şimşek, 2007: 99). Bilecik şehrinde yaşayan yerel halk için daha kısa mesafede erişilebilir rekreasyonel alanlara olan talep yüksektir. Ancak birçok kent sakini, şehirdeki rekreasyonel olanakları yetersiz bulmaktadır (Okuyucu, 2018: 4407). Bu nedenle bu çalışmada Bilecik şehrinde yaşayan yerel halkın rekreasyonel taleplerinin belirlenmesi, bu taleplerin daha çok hangi rekreasyonel kategoride olduklarının belirlenmesi amaçlanmıştır. Çalışmada ayrıca yerel halkın rekreasyonel talepleri ile sosyo-demografik özellikler arasındaki farklılıkların, rekreasyonel taleplerle ilişkisinin belirlenmesi amaçlanmıştır. Ölçekte yer alan 21 önermeye faktör analizi uygulanmıştır. Faktör analizi sonucuna göre, veriler dört faktör altında toplanmıştır. Katılımcılar sırasıyla; açık hava rekreasyon talepleri $(\bar{X}=4.25)$, kentsel rekreasyon talepleri $(\overline{\mathrm{X}}=3.97)$, sportif rekreasyon talepleri $(\overline{\mathrm{X}}=3.72)$ ve kapalı alan rekreasyon talepleri $(\overline{\mathrm{X}}=3.51)$ faktörlerine önem atfetmişlerdir. Buna göre, Bilecik şehrinde oluşturulacak rekreasyonel alanlar için önceliğin; açık hava, kentsel, sportif ve kapalı alan rekreasyon olanaklarına verilmesi yerinde olacaktır. Bilecik şehrinde en fazla açı hava rekreasyon taleplerine önem atfedilmiştir. Bu nedenle yerel yönetimlerin açık alanlarda gerçekleştirilebilecek boş zaman etkinlik mekânlarının sayısını arttırması öncelikle adım olmalıdır. Nitekim 31 Aralık 2019'da Çin'in Hubei eyaletinin Wuhan şehrinde ortaya çıkan coronavirus (2019-nCoV) ve virüsün dünyadaki hızlı yayılışı sonrasında, turizm ve rekreasyon talepleri değişmektedir, birçok yerde açık alan rekreasyonu taleplerinin artması kaçınılmazdır (Sağlık Bakanlığı, 2020). Katılımcıların rekreasyonel talepleri ikinci olarak kentsel rekreasyon $(\overline{\mathrm{X}}=3.97)$ alanlarına yönelik olmuştur. Buna göre Bilecik şehrinde açık veya kapalı spor tesisleri, eğlence yerleri, sinema, tiyatro, müzeler vb. gibi kentsel rekreasyon alanlarının oluşturulması ve kentsel planlamada bunlara yer verilmesi, yerel halkın taleplerinin karşılanmasında ve sürdürülebilir kent gelişiminde etkili olacaktır. Anketlerden elde edilen bulgulara göre, katılımcıların rekreasyonel taleplerinde üçüncü sırada sportif rekreasyon $(\overline{\mathrm{X}}=3.72$,) alanları oluşturulması yer almıştır. Günümüze rekreasyon anlayışının artması ile spor, boş zaman etkinliklerini gidermek için önemli bir araç haline gelmektedir. Ayrıca sağlıklı olma, yeni vücut bilinci gibi değişen değerler sporun rekreatif önemini arttırmaktadır (Karaküçük, 2008: 234, 238). Buna göre yerel yönetimlerin, kent içerisinde açık ve kapalı alanlarda, aktif ve pasif olarak katılım sağlanabilecek, sportif rekreasyon hizmeti sunan alanlar oluşturması, yerel halkın taleplerinin karşılanmasında etkili olacaktır. Bu bağlamda; kentteki çeşitli türdeki park, spor alanları, yürüyüş parkurları, futbol, tesis, yüzme vb. alanların arttırılması gerekmektedir. Çalışmada ortaya çıkan dördüncü faktör, kapalı alan rekreasyon talepleri $(\overline{\mathrm{X}}=3.51)$ olmuştur. Bilecik şehrinde; AVM, restoran, cafe vb. gibi kapalı ticari mekânlar oldukça yetersizdir. Ayrıca mevcut tesis ve işletmeler, öğrenci ve asker taleplerine yöneliktir. Buna karşıllk aile ve yetişkinlere yönelik alışveriş, yeme-içme vd. kolaylıklar oldukça azdır. Bu nedenle şehirdeki kapalı ve ticari rekreasyon alanlarının arttırılmasına yönelik girişimler, yerel yönetimler tarafından desteklenmeli ve kolaylaştırılmalıdır. 
Gerçekleştirilen $\mathrm{t}$ testi sonuçlarına göre, Bilecik şehrinde, "kentsel rekreasyon talepleri" faktörüne kadın katılımcılar daha fazla önem atfetmiştir $(\mathrm{p}<0.05)$. Buna göre Bilecik şehrinde, kadınlara yönelik; kentsel açık ve kapalı mekânlarda gerçekleştirilen rekreatif alanların yaratılması önem taşımaktadır. Bilecik şehrinde "sportif rekreasyon talepleri" faktörüne erkek katılımcılar kadın katılımcılara göre daha fazla önem atfetmiştir $(\mathrm{p}<0.05)$. Nitekim çeşitli çalışmalarda, kadınların ev işleri, çocukların bakımı, güvenlik algısı vb. gibi nedenlerden dolayı erkeklere göre fiziksel aktivitelere katılmalarının daha kısıtlı olduğu tespit edilmiştir (Gümüş vd., 2017: 36). Gerçekleştirilen $\mathrm{t}$ testi sonuçlarına göre, Bilecik şehrinde "kapalı alan rekreasyon talepleri" faktörü, medeni durum değişkenine göre anlamlı bir farklılık göstermiştir $(\mathrm{p}<0.05)$. Bu faktöre, bekar katılımcıların $(\bar{X}=3.62)$, evli katılımclara göre $(\bar{X}=3.41)$ kapalı alan rekreasyon talepleri daha fazladır ve istatistiksel olarak anlamlı bir farklılık göstermektedir. Bu bulguların oluşmasında evli ve çocuğa sahip bireylerin daha çok açık rekreasyon alanlarını tercih etmelerinin etkili olduğu düşünülmektedir.

ANOVA testi sonuçlarına göre ise "kapalı alan rekreasyon talepleri" faktörü ile gelir düzeyi arasında istatiksel olarak anlamlı bir farklılık bulunmaktadır ( $\mathrm{p}<0.05)$. Chick vd., (2015) bireylerin rekreasyonel etkinlik tercihlerinin gelir düzeyinin etkili olduğunu belirtmişlerdir. Bilecik şehrinde gelir düzeyi yükseldikçe restoran, AVM gibi kapalı alan rekreasyon talebi artmaktadır. Eğitim seviyesi yüksek bireylerin, sinema, tiyatro, opera, bale gibi kültürel faaliyetlere katılım oranı, eğitim seviyesi düşük bireylerden daha fazladır (Gözaydın ve Çiçek, 2012: 337). Bilecik son yıllarda sanayileşme ve hizmet sektörünün artması ile göç alan bir şehir haline gelmiştir. Ancak şehrin nüfusunun daha fazla artması, burada fabrika ve tesislerin kurulmasının yanı sıra sosyal tesisler ve kültürel olanakların artması ile olacaktır (Akcan ve Taşçı, 2017: 4). Bilecik şehrindeki sanayi ve hizmet sektöründe çalışan ve eğitim seviyesi daha yüksek olan kitlenin giderek artması rekreasyonel talepleri de arttırmaktadır. Araştırmadan elde edilen bulgulara göre, eğitim düzeyi değişkeni ile "kentsel rekreasyon talepleri" ve "kapalı alan rekreasyon talepleri" faktörleri arasında anlamlı farklılıklar tespit edilmiştir. Eğitim düzeyi yüksek olan grubun "kentsel rekreasyon talepleri" ve "kapalı alan rekreasyon talepleri" daha fazla olmuştur. Eğitim düzeyinin de etki ettiği, meslek grupları değişkeni de rekreasyonel taleplerin belirlenmesinde etkili olmaktadır. Bilecik şehrinde meslek grupları değişkenleri ile "kentsel rekreasyon talepleri" faktörü arasında da istatistiksel olarak anlamlı farklar bulunmuştur $(\mathrm{p}<0.05)$. Kamu çalışanlarının, işveren/kendi hesabına çalışanlara göre "kentsel rekreasyon talepleri" daha fazladır. Ayrıca "kapalı alan rekreasyon talepleri" faktörüne, kamu çalışanları ev hanımlarına göre daha fazla önem atfetmiştir ( $\mathrm{p}<0.05)$. Bilecik şehrinde salon sayısı 4, koltuk sayısı 240 olan 6 Eylül Kültür Merkezi sineması dışında sinema salonu bulunmamaktadır. Mevcut sinema rutubetli ve fiziki şartları iyi olmadığı için yerel halk sinema talebini başta Eskişehir ve Bursa gibi yakın şehirlerde (\%30.1) karşılamaktadır (Okuyucu, 2018: 4406). Bu nedenle Bilecik şehrinde hem "kentsel" hem de "kapalı alan" rekreasyon talebinin karşılanmasında öncelikle nitelikli bir sinema salonu açılması ve koltuk sayısının arttırılması yerinde olacaktır. Özellikle Bilecik şehrinde yaşayan kamu ve hizmet sektöründe çalışanların sayısının giderek artması bu yöndeki talepleri arttırmaktadir.

Çalışma sonucunda sosyo-demografik özelliklerin rekreasyonel talepleri etkiledikleri ve tercihler üzerinde etkili oldukları görülmüştür. Daha önce gerçekleştirilen çalışmalarda, sosyodemografik özellikler ve rekreasyonel talepler arasındaki ilişki, rekreasyonel alanların erişilebilirliği, güvenli olması, ekonomik olması, alanın kullanım sıklı̆̆ı ve rekreasyonel alanlardaki çevre sorunları açısından irdelenmiştir (Talay vd., 2010; Şişman vd., 2019). Bu çalışmada yerel halkın rekreasyonel talepleri gerçekleştirilen faktör analizi sonucunda; açık hava, kentsel, sportif ve kapalı alan rekreasyonu olmak üzere dört boyutta ortaya çıkmıştır. Bu çalışma ortaya çıkan boyutlar ile sosyo-demografik özellikler arasındaki farklılıkların belirlenmesi 
bakımından önemlidir. Bilecik şehrinde çalışmada belirlenen dört boyutta rekreasyonel yatırımların gerçekleştirilmesi, şehirde bir boş zaman endüstrisinin gelişmesine ve yerel halkın taleplerinin karşılanmasına katkı sağlayacaktır. Bu durum aynı zamanda kentte istihdam, yeni iş yerlerinin açılması, gelirlerin artması vb. gibi olumlu etkilerinin olmasına katkı sağlayacaktır. Yerel halkın boş zamanlarını verimli bir şekilde kullanabilecekleri alanların olması ve insanların dinlenme ve eğlenme gereksinimlerini karşılamaları; yaratma zevki, dostluk kurma, başarı, sağlık ve verimliliğin artması gibi pek çok faydayı da beraberinde getirecektir.

\section{KAYNAKÇA}

Akcan, C., ve Taşçı, Y. (2017). Bilecik İli İl İstihdam ve Mesleki Eğitim Kurulu 2017 Yılı Faaliyet Raporu. [Online]https://media.iskur.gov.tr/14265/bilecik-2017.pdf (Erişim Tarihi: 20.06.2020).

Akova, İ. (2013). Turizm Coğrafyası ve Planlama, (Editör) Günay Aktaş, S.: Turizm Coğrafyası içinde (ss.2-36) Eskişehir: Anadolu Üniversitesi Açıköğretim Fakültesi Yayınları.

Altınay, M. (2016). Kentsel Rekreasyon Alanlarında Hizmet Kalitesi: Ankara İli Örneği, Journal of Recreation and Tourism Research, 3 (2): 60-72.

Altintig, A. and Bagir, S. (2014). The Economic Conditions of Sakarya University Students and Their Participation to Recreation Activities, Social and Behavioral Sciences, 143: 88-91.

Buason, A. Eiriksdottir, K. Kristofersson, D. and Rickertsen, K. (2020). Frequency and Time in Recreational Demand, Journal of Environmental Economics and Policy, March: 1-31. DOI: $10.1080 / 21606544.2020 .1738963$

Büyüköztürk, Ş. (2015). Sosyal Bilimler İçin Veri Analizi El Kitabı. Ankara: Pegem Akademi.

Chan, N. W. and Wichman, C. J. (2018). The Effects of Climate on Leisure Demand: Evidence from North America. (Online) https://media.rff.org/documnts/RFF20WP2017-20-REV.pdf (Erişim Tarihi: 11.03.2020)

Chick, G., Hsu, Y. C. Yeh, C. K. and Hsieh, C. M. (2015). Leisure Constraints, Leisure Satisfaction, Life Satisfaction and Self-rated Health in Six Cities in Taiwan. Leisure Sciences, 37: 232-251.

Dall'Aste Brandolini, S. M. (2009). Recreational Demand Functions for Different Categories of Beach Visitor. Tourism Economics, 15(2): 339-365. doi:10.5367/000000009788254331

Eminağaoğlu, Z., Surat, H., Yavuz Özalp, A. ve Yaman, Y. K. (2016). Borçka Barajı Gölü ve Çevresi Rekreasyonel Alan Kullanım Olanaklarının Belirlenmesi. Kastamonu Üniversitesi Orman Fakültesi Dergisi, 16 (2): 348-361.

Gözaydın, G. ve Çiçek, G. (2012). Çanakkale İlinde Yaşayan Farklı Sosyo-Demografik Özelliklere Sahip Bireylerin Serbest Zaman Doyumlarının İncelenmesi, I. Rekreasyon Araştırmaları Kongresi, Kemer-Antalya, Bildiri Kitabı 12 - 15 Nisan 2012. Ankara. ISNB: 978-605-5437-79-4.

Gümüş, H., Alay Özgül, S. ve Karakılıç, M. (2017). Fiziksel Aktivite için Park ve Rekreasyon Alanlarına Gelen Kullanıcıların Mekân Seçimini ve Fiziksel Aktiviteye Katılımını Etkileyen Faktörler, Spormetre, 15 (1): 31-38.

Gürbüz, S. ve Şahin, F. (2015). Sosyal Bilimlerde Araştırma Yöntemleri Felsefe-Yöntemanaliz (2. Baskı). Ankara: Seçkin Yayıncılık.

Hall, C. M. and Page, S.J. (2006). The Geography of Tourism and Recreation Environment, Place and Space. Routledge: London and New York.

Karaküçük, S. (2008). Rekreasyon Boş Zamanları Değerlendirme (6. Baskı). Ankara: Gazi Kitabevi. 
Karaşah, B. (2017). Kentsel ve Kırsal Rekreasyon Alanlarına Yönelik Kullanıcı Tercihlerinin Belirlenmesi Artvin Kenti Örneği. Bartın Orman Fakültesi Dergisi, 19(1), 58-69. doi:10.24011/barofd.291998

Kaya, F. (2007). Bartın Kent Halkının Rekreasyonel Ĕ̆ilim ve Taleplerinin Belirlenmesi Üzerine Bir Araştırma, Yayınlanmamış Yüksek Lisans Tezi, Ankara Üniversitesi, Ankara.

Kılbaş Köktaş, Ş. (2004). Rekreasyon Boş Zaman Değerlendirme (3. Baskı). Ankara: Nobel Yayın Dağıtım.

Komossaa, F. Zanden, E., and Verburg, P. (2019). Characterizing Outdoor Recreation User Groups: A Typology of Peri-urban Recreationists in the Kromme Rijn Area, The Netherlands, Land Use Policy, 80: 246-258.

Kozak, N. ve Akoğlan Kozak, M. (2012). Genel Turizm Bilgisi (elektronik sürüm). Eskişehir: Anadolu Üniversitesi.

Kurar, İ. ve Baltacı, F. (2014). Halkın Boş Zaman Değerlendirme Alışkanlıkları: Alanya Örneği. International Journal of Science Culture and Sport, Special Issue 2: 39-52.

Kurtar, C., ve Somuncu, M. (2013). Kentsel Kültürel Mirasın Korunması ve Sürdürülebilirliği: Ankara Hamamönü Örneği. Ankara Araştırmaları Dergisi, 1(2): 35-47.

Lee, K. H. and Schuett, M. A. (2014). Exploring Spatial Variations in the Relationships Between Residents' Recreation Demand and Associated Factors: A case Study in Texas. Applied Geography, 53: 213-222.

Menteşe, S. (2019). Bilecik Şehir Merkezinde Kentsel Açık-Yeşil Alanların Değerlendirilmesi. Uluslararası Sosyal ve Beşeri bilimler Araştırma Dergisi, 6(33): 373-379.

Morelle, K. Buchecker, M. Kienast, F. and Tobias, S. (2018). Nearby Outdoor Recreation Modelling: An Agent-based Approach, Urban Forestry \& Urban Greening, 40: 286-298.

Okuyucu, A. (2018). Bilecik Kent Halkının Rekreasyonel Eğilim ve Taleplerinin Belirlenmesi, Journal of Social And Humanities Sciences Research (JSHSR), 5(30): 4400-4410.

Özgüç, N. (2003). Turizm Coğrafyası: Özellikler, Bölgeler. İstanbul: Çantay Kitabevi.

Özgür, E. M. (1994). Bilecik İlinde Farklı Karakterde İki Şehir: Bilecik ve Bozüyük. Ankara Üniversitesi Türkiye Coğrafyası Araştırma ve Uygulama Merkezi Dergisi, 3: 179-193.

Ryan, C. (2003). Recreational Tourism: Demand and Impacts. Clevedon: Channel View Publications.

Sağlık Bakanlığı (2020). 2019-nCoV Hastalı̆̆ı Sağlık Çalışanları Rehberi. [Online] https://hsgm.saglik.gov.tr/depo/haberler/ncov/2019nCov_Hastal_Salk_alanlar_Rehberi.pdf [Erişim: 10.06.2020].

Sağlık, A. ve Kelkit, A. (2014). Çanakkale Kent Halkının Rekreasyonel Eğilim ve Taleplerinin Belirlenmesi, ÇOMÜ Ziraat Fakültesi Dergisi, 2(1): 27-36.

Serbest Şimşek, D. (2007). Tekirdă̆ Merkez İlçe Kıyı Şeridi Rekreasyon Potansiyelinin Belirlenmesi Üzerine Bir Araştırma, Yayınlanmamış Yüksek Lisans Tezi, Namık Kemal Üniversitesi, Tekirdağ.

Sertkaya, Ş. (2001). Bartın İli Kıyı Bölgesinin Turizm ve Rekreasyon Potansiyelinin Saptanması ve Değerlendirilmesi Üzerine Bir Araştırma, Yayınlanmamış Doktora Tezi, Ankara Üniversitesi, Ankara.

Sharpley, R. (2006). Travel and Tourism. London: Sage Publications. 
Sievänen, T. Pouta, E. and Neuvonen, M. (2007). Recreational Home Users-potential Clients for Countryside Tourism?, Scandinavian Journal of Hospitality and Tourism, 7(3), 223-242.

Şişman, E. E. Özyavuz, M. ve Gültürk, P. (2019). Turizm ve Rekreasyonel Tercihlerin Demografik Yapıya Göre Değişiminin Tekirdağ Örneğinde İncelenmesi. Bartın Orman Fakültesi Dergisi, 21(3): 589-596.

Talay, İ. Kaya, F. ve Belkayalı, N. (2010). Sosyo-Ekonomik Yapının Rekreasyonel Eğilim ve Talepler Üzerine Etkisi: Bartın Kenti Örneği. Coğrafi Bilimler Dergisi, 8 (2): 147-156.

TDK, (2020). Güncel Türkçe Sözlük. https://sozluk.gov.tr/ [Erişim Tarihi: 20.05.2020]

TÜIKK. (2018). Adrese Dayalı Nüfus Kayıt Sistemi Sonuçları, https://biruni.tuik.gov.tr/medas/?kn=106\&locale=tr [Erişim Tarihi: 11.11.2017]

Usta, Ö (2014). Turizm Genel ve Yapısal Yaklaşım. Ankara: Detay Yayıncllı.

Willibald, F., van Strien, M. J., Blanco, V. and Grêt-Regamey, A. (2019). Predicting Outdoor Recreation Demand on a National Scale-The Case of Switzerland, Applied Geography, 113: 1-13.

Yazıcıoğlu, Y. ve Erdoğan, S. (2004). SPSS Uygulamalı Bilimsel Araştırma Yöntemleri. Ankara: Detay Yayıncılık.

Yersüren, S. ve Özel, Ç, H., (2020). Boş Zaman ve Rekreasyon Konulu Tezler Üzerine Bibliyometrik Bir Çalışma, Türk Turizm Araştırmaları Dergisi, 4(2): 1139-1159. 